\title{
Indoor Air Quality Assessment of the San Francisco Federal Building
}

\author{
Michael G. Apte, Deborah H. Bennett ${ }^{*}$, David Faulkner, Randy L. \\ Maddalena, Marion L. Russell, Michael Spears, Douglas P Sullivan and \\ Amber L. Trout ${ }^{*}$ \\ Environmental Energy Technologies Division \\ Indoor Environment Department \\ Lawrence Berkeley National Laboratory \\ Berkeley, CA 94720 \\ * Environmental and Occupational Health Group \\ Department of Public Health Sciences \\ U.C. Davis
}

July 12, 2009

This work was supported by interagency agreement PX0008425 from General Services Administration (GSA) and also the Assistant Secretary for Energy Efficiency and Renewable Energy, Office of Building Technologies of the U.S. Department of Energy under Contract No. DE-AC02-05CH11231. 


\section{Indoor Air Quality Assessment of the San Francisco Federal Building}

Michael G. Apte, Deborah H. Bennett ${ }^{*}$, David Faulkner, Randy L. Maddalena, Marion L. Russell, Michael Spears, Douglas P Sullivan and Amber L. Trout ${ }^{*}$

$$
12 \text { July, } 2009
$$

Indoor Environment Department Environmental Energy Technologies Division

Lawrence Berkeley National Laboratory

* Environmental and Occupational Health Group, Department of Public Health Sciences, U.C. Davis 


\begin{abstract}
An assessment of the indoor air quality (IAQ) of the San Francisco Federal Building (SFFB) was conducted on May 12 and 14, 2009 at the request of the General Services Administration (GSA). The purpose of the assessment was for a general screening of IAQ parameters typically indicative of well functioning building systems. One naturally ventilated space and one mechanically ventilated space were studied. In both zones, the levels of indoor air contaminants, including $\mathrm{CO}_{2}$, $\mathrm{CO}$, particulate matter, volatile organic compounds, and aldehydes, were low, relative to reference exposure levels and air quality standards for comparable office buildings. We found slightly elevated levels of volatile organic compounds (VOCs) including two compounds often found in "green" cleaning products. In addition, we found two industrial solvents at levels higher than typically seen in office buildings, but the levels were not sufficient to be of a health concern. The ventilation rates in the two study spaces were high by any standard. Ventilation rates in the building should be further investigated and adjusted to be in line with the building design. Based on our measurements, we conclude that the IAQ is satisfactory in the zone we tested, but IAQ may need to be re-checked after the ventilation rates have been lowered.
\end{abstract}

\title{
Introduction
}

We conducted an assessment of the indoor air quality (IAQ) of the San Francisco Federal Building (SFFB) on May 12 and 14, 2009 at the request of the General Services Administration (GSA). The purpose of the assessment was for a general screening of IAQ parameters typically indicative of well functioning building systems. The screening was conducted jointly by the Commercial Building Ventilation and Indoor Air Quality Group at LBNL and Professor Deborah Bennett and the Environmental and Occupational Health Group, Department of Public Health Sciences at the University of California, Davis. This joint team has developed a protocol for ventilation and IAQ assessment of spaces with floor areas of 1000 to 50,000 square feet. Although the SFFB is far larger, the individually ventilated wings on each floor are well within the size range that the protocol is designed to study. Per GSA's request, the assessment consisted of an evaluation of one naturally ventilated wing (Floor 15 East, May 12, 2009), and one mechanically ventilated wing (Floor 5 East, May 14, 2009).

\section{Results}

The Methods used to conduct this study are detailed in Appendix A of this report.

\section{Floor 15 - Natural Ventilation}

The overall ventilation rate for Floor 15 was approximately 1.6 air changes per hour, translating into an outside air supply rate of approximately 2900 cubic feet per minute $(\mathrm{cfm})$ or $0.36 \mathrm{cfm} \mathrm{ft}^{-2}$. The observed workday average occupancy of this wing was 21 (plus field study staff of 5.5). The approximate per-person outside air ventilation rate was $140 \mathrm{cfm}_{\text {person }}{ }^{-1}$.

Daily average temperatures from the two carts and outdoors were $74.3 \pm 1.3,76.7 \pm 2.1^{\circ} \mathrm{F}$, and $68.0 \pm 9^{\circ} \mathrm{F}$, respectively. Daily maximum temperatures were $76.9^{\circ} \mathrm{F}, 78.8^{\circ} \mathrm{F}$, and 
$89.4^{\circ} \mathrm{F}$ respectively. Daily average RHs from the two carts and outdoors were $36.5 \pm 3.5$ $\% \mathrm{RH}, 32.6 \pm 1.2 \% \mathrm{RH}$, and 51.8 $\pm 9.8 \% \mathrm{RH}$, respectively. Daily maximum RHs were $53.1 \% \mathrm{RH}, 39.8 \% \mathrm{RH}$, and $58.7 \% \mathrm{RH}$ respectively.

Carbon dioxide concentrations were low in this space. Daily average concentrations from the two carts and outdoors were $567 \pm 45 \mathrm{ppm}, 550 \pm 58 \mathrm{ppm}$, and $428 \pm 30 \mathrm{ppm}$, respectively. Daily maximum concentrations were 670 ppm, 680 ppm, and 510 ppm, respectively. Indoor and outdoor average $\mathrm{CO}$ concentrations were $0.0 \pm 0.1 \mathrm{ppm}$ and $0.7 \pm 0.5 \mathrm{ppm}$, respectively. Daily maximum indoor and outdoor CO concentrations were $1.4 \mathrm{ppm}$, and $2.6 \mathrm{ppm}$, respectively.

Table 1 show indoor and outdoor particulate matter concentrations with aerodynamic diameters 2.5 microns and below $\left(\mathrm{PM}_{2.5}\right)$ measured with the Met-One particle counter, assuming a particle density of $1 \mathrm{~g} \mathrm{cc}^{-1}$. $\mathrm{PM}_{2.5}$ concentrations measured indoors on the two Floor 15 and outside locations were $2.2 \pm 0.6 \mu \mathrm{g} \mathrm{m}^{-3}, 3.6 \pm 1.1 \mu \mathrm{g} \mathrm{m}^{-3}$, and $1.3 \pm 0.4 \mu \mathrm{g} \mathrm{m}^{-3}$, respectively. Maximum concentrations indoors and outdoors were $4.3 \mu \mathrm{g} \mathrm{m}^{-3}, 6.4 \mu \mathrm{g} \mathrm{m}^{-3}$, and $4.1 \mu \mathrm{g} \mathrm{m}^{-3}$, respectively. Table 2 shows total indoor total ultrafine particle count concentrations were $5600 \pm 1800 \mathrm{~cm}^{-3}$. Maximum particle concentrations were 11,000 $\mathrm{cm}^{-3}$. The outdoor optical particle counter data were inadvertently not saved for this study date. Table 3 Aethalometer data show indoor and outdoor black carbon particle concentrations were $310 \pm 110 \mathrm{ng} \mathrm{m}^{-3}$, and $870 \pm 840 \mathrm{ng} \mathrm{m}^{-3}$, respectively. Maximum indoor and outdoor particle concentrations were $600 \mathrm{ng} \mathrm{m}^{-3}$ and $6200 \mathrm{ng} \mathrm{m}^{-3}$, respectively.

Table 4a shows VOC and aldehyde concentrations measured on Floor 15E. The table also lists comparison data from a review published concentrations from measurements of VOCs commonly found in office buildings (Hodgson and Levin, 2003). The list of analytes selected for study and shown in Table 4a were chosen to span a range of sources from outdoor air (automobile emissions), building materials, cleaning supplies, office equipment, furniture, personal hygiene products, etc. Formaldehyde is a common indoor contaminant or concern. The average measured formaldehyde concentration on Floor 15E was $7.9 \mu \mathrm{g} \mathrm{m}^{-3}$, while the outdoor concentration was $3.3 \mu \mathrm{g} \mathrm{m}^{-3}$. The comparison central tendency (CT) concentration from Hodgson and Levin (2003) was $15.7 \mu \mathrm{g} \mathrm{m}^{-3}$ (maximum from office buildings was $44 \mu \mathrm{g} \mathrm{m}^{-3}$ ). Acetaldehyde is also often of concern; its concentration was $3.4 \mu \mathrm{g} \mathrm{m}^{-3}$ relative to the comparison CT concentration of $7.8 \mu \mathrm{g}$ $\mathrm{m}^{-3}$. VOCs measured on Floor 15E at levels greater than the comparison CT concentration were methylene chloride (19 $\mu \mathrm{g} \mathrm{m}^{-3}$ vs. $\left.1.4 \mu \mathrm{g} \mathrm{m}^{-3}\right)$; 2-butoxyethanol (7.5 $\mu \mathrm{g} \mathrm{m}^{-3}$ vs. $\left.3.1 \mu \mathrm{g} \mathrm{m}^{-3}\right)$; d-limonene $\left(7.4 \mu \mathrm{g} \mathrm{m}^{-3}\right.$ vs. $\left.6.7 \mu \mathrm{g} \mathrm{m}^{-3}\right)$; and diethylphthalate $\left(0.19 \mu \mathrm{g} \mathrm{m}^{-3}\right.$ vs. $\left.0.05 \mu \mathrm{g} \mathrm{m}^{-3}\right)$.

\section{Floor 5 - Mechanical Ventilation}

The overall ventilation rate for Floor 5 was approximately 3.8 air changes per hour, translating into an outside air supply rate of approximately $4100 \mathrm{cfm}$ or $0.50 \mathrm{cfm} / \mathrm{ft}^{2}$. The observed workday average occupancy of this wing was 6 (plus field study staff of 4). The approximate per-person outside air ventilation rate was $690 \mathrm{cfm}_{\text {person }}{ }^{-1}$. 
Daily average temperatures from the two carts and outdoors were $76.3 \pm 1.2^{\circ} \mathrm{F}$, $74.3 \pm 1.5^{\circ} \mathrm{F}$, and $65.7 \pm 4.9^{\circ} \mathrm{F}$, respectively. Daily maximum temperatures were $78.1^{\circ} \mathrm{F}$, $77.7^{\circ} \mathrm{F}$, and $78.6^{\circ} \mathrm{F}$ respectively. Daily average RHs from the two carts and outdoors were 42.4 $\pm 1.2 \% \mathrm{RH}, 37.0 \pm 1.1 \% \mathrm{RH}$, and 43.1 $\pm 9.1 \% \mathrm{RH}$, respectively. Daily maximum RHs were $44.5 \% \mathrm{RH}, 43.2 \% \mathrm{RH}$, and $75.2 \% \mathrm{RH}$ respectively.

As with Floor 15, $\mathrm{CO}_{2}$ concentrations were low in this space. Daily average concentrations from the two carts and outdoors were $440 \pm 30 \mathrm{ppm}, 440 \pm 30 \mathrm{ppm}$, and $452 \pm 10$ ppm, respectively. Daily maximum concentrations were 540 ppm, 510 ppm, and $460 \mathrm{ppm}$, respectively. Indoor and outdoor average CO concentrations were $0.0 \pm 0.0 \mathrm{ppm}$ and $0.8 \pm 0.3 \mathrm{ppm}$, respectively. Daily maximum indoor and outdoor CO concentrations were $0.0 \mathrm{ppm}$, and $2.1 \mathrm{ppm}$, respectively.

Again from Table 1, $\mathrm{PM}_{2.5}$ concentrations measured indoors on the Floor 5 and outside were $0.6 \pm 0.2 \mu \mathrm{g} \mathrm{m}^{-3}$ and $3.7 \pm 0.6 \mu \mathrm{g} \mathrm{m}^{-3}$, respectively. Maximum concentrations indoors and outdoors were $2.1 \mu \mathrm{g} \mathrm{m}^{-3}$, and $5.4 \mu \mathrm{g} \mathrm{m}^{-3}$, respectively. The Met-One particle counter for Cart 2 was inadvertently not turned on during the Floor 5 study day. Total indoor and outdoor total ultrafine particle count concentrations were 1,400 $\pm 840 \mathrm{~cm}^{-3}$ and $20,000 \pm 14,000 \mathrm{~cm}^{-3}$, respectively. Indoor and outdoor maximum particle concentrations were $570 \mathrm{~cm}^{-3}$ and $61,000 \mathrm{~cm}^{-3}$, respectively. Aethalometer ${ }^{\mathrm{TM}}$ data (Table 3) show two indoor locations and outdoor location black carbon particle concentrations were $96 \pm 27 \mathrm{ng}$ $\mathrm{m}^{-3}, 280 \pm 120 \mathrm{ng} \mathrm{m}^{-3}$ and $450 \pm 760 \mathrm{ng} \mathrm{m}^{-3}$, respectively. Maximum particle concentrations were $190 \mathrm{ng} \mathrm{m}^{-3}, 700 \mathrm{ng} \mathrm{m}^{-3}$, and $6400 \mathrm{ng} \mathrm{m}^{-3}$, respectively.

Table 4b continues from 4a, showing VOC and aldehyde concentrations measured on Floor 5E. The average measured formaldehyde concentration on Floor 5E was 4.6 $\mu \mathrm{g}$ $\mathrm{m}^{-3}$, while the outdoor concentration was $3.7 \mu \mathrm{g} \mathrm{m}^{-3}$. The comparison central tendency (CT) concentration from Hodgson and Levin (2003) was $15.7 \mu \mathrm{g} \mathrm{m}^{-3}$ (maximum from office buildings was $44 \mu \mathrm{g} \mathrm{m}^{-3}$ ). Acetaldehyde is also often of concern; its concentration was $3.8 \mu \mathrm{g} \mathrm{m}^{-3}$ relative to the comparison CT concentration of $7.8 \mu \mathrm{g} \mathrm{m}^{-3}$. VOCs measured on Floor 15E at levels greater than the comparison CT concentration were nhexane (12 $\mathrm{g} \mathrm{m} \mathrm{m}^{-3}$ vs. $2.2 \mu \mathrm{g} \mathrm{m}^{-3}$ ); methylene chloride (58 $\mu \mathrm{g} \mathrm{m}^{-3}$ vs. $1.4 \mu \mathrm{g} \mathrm{m}^{-3}$ ); and diethylphthalate $\left(0.1 \mu \mathrm{g} \mathrm{m}^{-3}\right.$ vs. $\left.0.05 \mu \mathrm{g} \mathrm{m}^{-3}\right)$.

\section{Discussion}

The measurements made in the SFFB provide a fairly clear picture of the IAQ of the building, at least in the spaces measured, but likely as a representation of the building as a whole. One striking observation by the study team was the very low occupant density in the two spaces studied, particularly Floor 5 East where only six occupants were present. It was not obvious whether this was normal, or due to staffing changes.

The ventilation rate in the naturally ventilated space, $0.36 \mathrm{cfm} \mathrm{ft}^{-2}$, can be compared to rates measured in the BASE Study, a probability sample of ventilation and IAQ in100 large office buildings in the U.S., conducted by the U.S. EPA (Persily and Gorfain, 2004). The median volumetric ventilation rate in this study was $0.2 \mathrm{cfm} \mathrm{ft}^{-2}$ and the $75^{\text {th }}$ percentile rate was $0.53 \mathrm{cfm} \mathrm{ft}^{-2}$. Assuming the BASE data are representative of U.S. 
offices, roughly $60 \%$ of U.S. office buildings have less air flow supplied to the space than Floor 15E. When looked at from the perspective of $\mathrm{cfm}$ per person however, the $75^{\text {th }}$ percentile outdoor air supply rate in the BASE study was $144 \mathrm{cfm}_{\text {person }}{ }^{-1}$, very close to the $140 \mathrm{cfm}_{\text {person }}{ }^{-1}$ observed in Floor 15E. However, the BASE measurements included many periods when ventilation rates were elevated above the minimum value due to economizer operation. From the standpoint of the ASHRAE minimum ventilation standard 62.1 for commercial buildings (ASHRAE 2007), which recommends $0.06 \mathrm{cfm}$ $\mathrm{ft}^{-2}$ and $5 \mathrm{cfm}$ person ${ }^{-1}$, or $600 \mathrm{cfm}$ for the space, the ventilation rate is about a factor of 5 higher than required.

A parallel analysis of Floor 5E places its value of $0.50 \mathrm{cfm} \mathrm{ft}^{-2}$ in the top $75^{\text {th }}$ of measured U.S. commercial building ventilation rates. On a per-person basis, the $690 \mathrm{cfm} \mathrm{person}^{-1}$ is above the $90^{\text {th }}$ percentile of ventilation rates in the U.S as measured in the BASE study. Again, the ASHRAE 62.1 ventilation rate for the observed occupancy and floor area would be $525 \mathrm{cfm}$. The measured $4100 \mathrm{cfm}$ is a factor of 8 times greater than required by ASHRAE 62.1.

It is clear that both spaces are over-ventilated relative to standards for reasons far beyond the low occupancy. To bring the measured ventilation into line with the LEED credit for $30 \%$ outside air supply over ASHRAE 62.1 would require 350 occupants in Floor 15E and 540 occupants in Floor 5E! The energy implications of this over-ventilation are likely to be significant, particularly in the mechanically ventilated spaces.

ASHRAE Standard 55 (2004) provides guidance for thermal comfort based on room temperature, humidity, air movement, occupant clothing levels and metabolic activity. Assuming normal clothing values and sedentary activity levels in the two spaces that were studied, the measured thermal conditions fall within the definition of acceptable thermal comfort where the temperature ranges from about $72^{\circ} \mathrm{F}$ to $81^{\circ} \mathrm{F}$ and $30 \% \mathrm{RH}$ to $60 \% \mathrm{RH}$.

Indoor $\mathrm{CO}_{2}$ levels were extremely low, in both spaces. This is due to the high per-person ventilation rates. In Floor $5 \mathrm{E}$ the levels are indistinguishable from the measured outdoor $\mathrm{CO}_{2}$ concentrations. Likewise, $\mathrm{CO}$ concentrations were very low, reflecting low outdoor levels and a presumed lack of indoor combustion sources.

The measured particle concentrations using all three instruments indicated very low concentrations. Floor 5E had considerably lower $\mathrm{PM}_{2.5}$, ultrafine particles, and black carbon than Floor 15E. No doubt, this was due to the differences in the ventilation approaches, including the filtration system in the Floor 5E air handler. Indoor particle concentrations in the mechanically-ventilated Floor $5 \mathrm{E}$ were lower than outdoor concentrations, which is likely a consequence of the sealed windows and particle filtration, while concentrations in the naturally-ventilated Floor 15E were slightly higher than outdoor concentrations. Outdoor particle levels were also low relative to the $\mathrm{PM}_{2.5}$ Federal Ambient Air Quality Criteria ( $35 \mu \mathrm{g} \mathrm{m}^{-3} 24$ hour averaging time). 
Indoor VOC and aldehyde concentrations were generally low reflecting an absence of significant sources. Formaldehyde is sometimes of concern in office buildings, but in the case of both floors, the levels were far below the central tendency concentrations for office buildings in the literature and below the $9 \mu \mathrm{g} \mathrm{m}^{-3}$ Chronic (8-hr) Reference Exposure Level (REL, OEHHA 2008). Similarly the acetaldehyde levels were far below the chronic REL of $140 \mu \mathrm{g} \mathrm{m}^{-3}$ set by OEHHA. In Floor 15E the source of methylene chloride is unclear, however it may be from use of freshly printed material or a cleaning solvent. The 2-butoxyethanol and d-limonene are common ingredients in "green" cleaning products - the higher than usual levels of these compounds may reflect the "green" cleaning practices of GSA. It is somewhat interesting that Floor 5E had somewhat elevated n-hexane and methylene chloride, relative to the concentrations in most office buildings. These are both used as industrial solvents, but again may be from a printing process. The Chronic RELs for n-hexane and methylene chloride are $7000 \mu \mathrm{g} \mathrm{m}^{-}$ ${ }^{3}$ and $400 \mu \mathrm{g} \mathrm{m}^{-3}$, respectively (OEHHA 2008).

Given the collection of data from only two floors and the low measured levels of indoor pollutants, except as noted above, comparisons of pollutant concentrations in the naturally ventilated floor with those in the more conventional mechanically-ventilated floor would not be meaningful. The exception is the higher indoor-to-outdoor concentration ratio for particles in the naturally ventilated floor - an expected finding because the naturally ventilated floor does not recirculate indoor or incoming outdoor air through particle filters. Given the low measured concentrations on both floors, the lack of sheltering from outdoor particles in the naturally ventilated floor is likely insignificant. However, in locations of the country where outdoor particle concentrations are often elevated relative to applicable standards, the lack of sheltering from outdoor particles in naturally-ventilated buildings may be of concern.

\section{Conclusions and Recommendations}

The investigation of the ventilation and IAQ in the San Francisco Federal Building on one naturally ventilated floor and one mechanically ventilated floor suggests that the IAQ is quite good for both these areas, and probably representative of the building as a whole. None of the often-observed selected indoor contaminants that were measured appear to be present at levels of concern. However, ventilation rates in the two spaces were high relative to minimum requirements and potentially wasteful of energy. If the ventilation rates are lowered, indoor pollutant concentrations would increase due to less dilution.

It is recommended that the ventilation rates throughout the building be monitored and adjusted to match occupancy, and be re-set to the design values for the building, or $30 \%$ above the ASHRAE 62.1 minimum ventilation standard. It is further recommended that with these changes a re-assessment of IAQ be conducted to establish the concentrations at the new ventilation rates.

\section{Acknowledgements}

This work was supported by interagency agreement PX0008425 from General Services Administration (GSA) and also the Assistant Secretary for Energy Efficiency and Renewable Energy, Office of Building Technologies of the U.S. Department of Energy 
under Contract No. DE-AC02-05CH11231. Its contents are solely the responsibility of the authors and do not necessarily represent the official views of GSA or US DOE. We thank Warren Sitterley and Angel Gonzalez of GSA and Steve Casey of Enovity, Inc. for their support in accessing the study sites in the SFFB. Thanks also to William Fisk and Richard Diamond of LBNL for their reviews of this report. We also thank the staff of the SFFB for their support and patience during the study dates in their office spaces.

\section{References}

ASHRAE. 1999. ANSI/ASHRAE Standard 129-199, Measuring Air Change Effectiveness. American Society of Heating, Refrigeration, and Air-Conditioning Engineers, Atlanta GA.

ASHRAE. 2004. ANSI/ASHRAE Standard 55, Thermal Environmental Conditions for Human Occupancy. American Society of Heating, Refrigeration, and Air-Conditioning Engineers, Atlanta GA.

ASHRAE. 2007. ANSI/ASHRAE Standard 62.1, Ventilation for Acceptable Indoor Air Quality. American Society of Heating, Refrigeration, and Air-Conditioning Engineers, Atlanta GA.

Hodgson A.T. and Levin H. 2003. Classification of Measured Indoor Volatile Organic Compounds Based on Noncancer Health and Comfort Considerations. Lawrence Berkeley National Laboratory, Berkeley CA. LBNL-53308.

OEHHA 2008. "Revised Air Toxics Hot Spots Program,” California Office of Health Hazards Assessment, http://www.oehha.ca.gov/air/hot_spots/rels_dec2008.html and http://www.oehha.org/air/allrels.html

Persily A. and Gorfain J. 2004. Analysis of Ventilation Data from the U.S. Environmental Protection Agency Building Assessment Survey and Evaluation (BASE) Study, National Institute of Standards and Technology, Gaithersburg MD. NISTIR 7145.

\section{TABLES}

Table 1. Measured indoor and outdoor $\mathrm{PM}_{2.5}$ concentrations in the San Francisco Federal Building on May 12 and 14, 2009.

\begin{tabular}{lllll}
\hline \multicolumn{1}{c}{ Location (Cart) } & \multicolumn{2}{c}{ Indoor $\left(\mu \mathrm{g} \mathrm{m}^{-3}\right)$} & \multicolumn{2}{c}{ Outdoor $\left(\mu \mathrm{g} \mathrm{m}^{-3}\right)$} \\
& Avg (stdev) & Max & Avg (stdev) & Max \\
\hline Floor 15 (1) & $2.2(0.6)$ & 4.3 & $1.3(0.4)$ & 4.1 \\
Floor 15(2) & $3.6(1.1)$ & 6.4 & & \\
Floor 5 (1) & $0.6(0.2)$ & 2.1 & $3.7(0.6)$ & 5.4 \\
\hline
\end{tabular}

Table 2. Measured total indoor and outdoor ultrafine particle concentrations in the San Francisco Federal Building on May 12 and 14, 2009.

\begin{tabular}{llrll}
\hline \multicolumn{1}{c}{ Location } & \multicolumn{2}{c}{ Indoor $\left(\# \mathrm{~cm}^{-3}\right)$} & \multicolumn{2}{c}{ Outdoor $\left(\# \mathrm{~cm}^{-3}\right)^{\mathrm{a}}$} \\
& Avg (stdev) & \multicolumn{1}{c}{ Max } & Avg (stdev) & \multicolumn{1}{c}{ Max } \\
\hline Floor 15 & $5,600(1,800)$ & 10,900 & & \\
Floor 5 & $1,400(840)$ & 570 & $20,000(14,000)$ & 61,000 \\
\hline
\end{tabular}


${ }^{\mathrm{a}}$ Outdoor particle number concentration data for Floor 15 measurement day were lost.

Table 3. Measured indoor and outdoor black carbon aerosol concentrations measured with Aethalometers $^{\mathrm{TM}}$ in the San Francisco Federal Building on May 12 and 14, 2009.

\begin{tabular}{lllll}
\hline \multicolumn{1}{c}{ Location (Cart) } & \multicolumn{2}{c}{ Indoor $\left(\mathrm{ng} \mathrm{m}^{-3}\right)$} & \multicolumn{2}{c}{ Outdoor $\left(\mathrm{ng} \mathrm{m}^{-3}\right)$} \\
& Avg (stdev) & Max & Avg (stdev) & Max \\
\hline Floor 15 (1) & $310(111)$ & 600 & $860(840)$ & 6,200 \\
Floor 5 (2) & $96(27)$ & 190 & $450(760)$ & 6,400 \\
Floor 5 (1) & $280(120)$ & 700 & & \\
\hline
\end{tabular}

Table 4a. Indoor (I) and outdoor (O) VOC and aldehyde measurements from the San Francisco Federal Building from Floor 15 East (naturally ventilated), collected on $5 / 12 / 2009$. Also shown are central tendency and maximum concentrations measured in office buildings from Hodgson and Levin 2003.

\begin{tabular}{|c|c|c|c|c|c|c|}
\hline $5 / 12 / 09$ & $\begin{array}{c}\text { Avg } \\
\text { Inside } \\
\mu g \mathrm{~m}^{-3}\end{array}$ & $\begin{array}{c}\text { Outside } \\
\text { Roof } \\
\mu \mathrm{g} \mathrm{m}^{-3}\end{array}$ & I/O Ratio & Avg I-O & $\begin{array}{c}\text { Central } \\
\text { Tendency } \\
\mu \mathrm{g} \mathrm{m}^{-3}\end{array}$ & $\mu \mathrm{g} \mathrm{m}^{-3}$ \\
\hline n-hexane & 2.14 & 0.05 & 39.1 & 2.09 & 2.18 & 10.9 \\
\hline methylene chloride & 18.8 & 2.28 & 8.24 & 16.5 & 1.39 & 225 \\
\hline carbon tetrachloride & 0.60 & 0.74 & 0.82 & -0.13 & 0.00 & 3.90 \\
\hline chloroform & 0.12 & 0.04 & 2.86 & 0.08 & 0.00 & 9.76 \\
\hline benzene & 0.34 & 0.35 & 0.98 & -0.01 & 3.19 & 12.1 \\
\hline trichloroethylene & 0.02 & 0.01 & 4.96 & 0.02 & 9.68 & 25.8 \\
\hline toluene & 1.14 & 0.76 & 1.50 & 0.38 & 7.92 & 151 \\
\hline tetrachloroethylene & 0.35 & 0.22 & 1.59 & 0.13 & 3.20 & 25.9 \\
\hline hexanal & 2.13 & 0.60 & 3.52 & 1.52 & 1.93 & 9.84 \\
\hline ethylbenzene & 0.39 & 0.18 & 2.14 & 0.21 & 2.09 & 11.3 \\
\hline $\mathrm{m} / \mathrm{p}$-xylene & 0.83 & 0.55 & 1.52 & 0.28 & 6.09 & 43.5 \\
\hline a-pinene & 0.30 & 0.07 & 4.30 & 0.23 & 0.22 & 8.33 \\
\hline o-xylene & 0.42 & 0.22 & 1.88 & 0.19 & 2.87 & 15.2 \\
\hline styrene & 0.17 & 0.01 & 11.6 & 0.15 & 1.70 & 5.11 \\
\hline 2-butoxyethanol & 7.54 & 0.10 & 75.4 & 7.44 & 3.14 & 67.6 \\
\hline d-limonene & 7.39 & 0.09 & 82.5 & 7.30 & 6.67 & 66.7 \\
\hline benzaldehyde & 1.32 & 1.87 & 0.70 & -0.55 & 2.04 & 6.52 \\
\hline 1,4-dichlorobenzene & 0.21 & 0.02 & 10.3 & 0.19 & 0.18 & 42.7 \\
\hline octanal & 1.14 & 0.28 & 4.03 & 0.86 & NA & NA \\
\hline decamethylcyclopent & & 1.03 & 10.2 & 9.44 & NA & NA \\
\hline a-siloxane & 10.5 & & & & & \\
\hline nonanal & 2.65 & 0.61 & 4.36 & 2.05 & 3.02 & 8.14 \\
\hline phenol & 1.21 & 0.66 & 1.84 & 0.56 & NA & 9.62 \\
\hline naphthalene & 0.07 & 0.03 & 2.76 & 0.04 & NA & 9.95 \\
\hline decanal & 4.54 & 1.06 & 4.27 & 3.48 & NA & NA \\
\hline a-terpineol & 0.02 & 0.01 & 4.35 & 0.02 & NA & NA \\
\hline TXIB $^{\mathrm{a}}$ & 0.29 & 0.02 & 18.9 & 0.28 & 2.35 & 10.4 \\
\hline diethylphthalate & 0.19 & 0.01 & 18.1 & 0.18 & 0.05 & 6.00 \\
\hline formaldehyde & 7.87 & 3.31 & 2.38 & 4.56 & 15.7 & 44.2 \\
\hline acetaldehyde & 3.37 & 1.00 & 3.37 & 2.37 & 7.76 & 17.2 \\
\hline acetone & 13.4 & 9.68 & 1.38 & 3.75 & NA & NA \\
\hline
\end{tabular}


Table 4b. Indoor (I) and outdoor (O) VOC and aldehyde measurements from the San Francisco Federal Building from Floor 5 East (mechanically ventilated), collected on $5 / 14 / 2009$. Also shown are central tendency and maximum concentrations measured in office buildings from Hodgson and Levin 2003.

\begin{tabular}{|c|c|c|c|c|c|c|}
\hline $5 / 14 / 09$ & $\begin{array}{l}\text { Avg } \\
\text { Inside } \\
\mu \mathrm{g} \mathrm{m}^{-3}\end{array}$ & $\begin{array}{l}\text { Outside } \\
\text { Roof } \\
\mu \mathrm{g} \mathrm{m}^{-3}\end{array}$ & $\begin{array}{l}\text { I/O Ratio } \\
\mu \mathrm{g} \mathrm{m}^{-3}\end{array}$ & 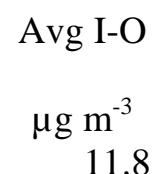 & $\begin{array}{c}\text { Central } \\
\text { Tendency } \\
\mu \mathrm{g} \mathrm{m}^{-3} \\
2.18\end{array}$ & $\begin{array}{r}\operatorname{Max} \\
\mu \mathrm{g} \mathrm{m}^{-3} \\
10 . \varsigma\end{array}$ \\
\hline n-hexane & 11.8 & 0.01 & 2350 & 11.8 & 2.18 & 10.5 \\
\hline methylene chloride & 58 & 0.01 & 11600 & 58 & 1.39 & 225 \\
\hline rbon tetrachloride & 0.57 & 0.01 & 114 & 0.57 & NA & 3.90 \\
\hline chloroform & 0.07 & 0.06 & 1.19 & 0.01 & NA & 9.76 \\
\hline nzene & 0.29 & 0.17 & 1.75 & 0.13 & 3.19 & 12.1 \\
\hline chloroethylene & 0.00 & 0.01 & 0.83 & 0.00 & 9.68 & 25.8 \\
\hline luene & 1.55 & 0.01 & 309 & 1.54 & 7.92 & 151 \\
\hline rachloroethylene & 0.14 & 0.01 & 28.8 & 0.14 & 3.20 & $25 . c$ \\
\hline xanal & 1.12 & 0.13 & 8.88 & 1.00 & 1.93 & 9.84 \\
\hline lbenzene & 0.23 & 0.12 & 2.00 & 0.12 & 2.09 & 11.3 \\
\hline -xylene & 0.72 & 0.38 & 1.88 & 0.34 & 6.09 & 43.5 \\
\hline nene & 0.11 & 0.04 & 2.68 & 0.07 & 0.22 & 8.33 \\
\hline lene & 0.28 & 0.15 & 1.91 & 0.13 & 2.87 & 15.2 \\
\hline en & 0.08 & 0.03 & 2.45 & 0.05 & 1.70 & 5.11 \\
\hline butoxyethanol & 0.80 & 0.01 & 93.1 & 0.79 & 3.14 & 67.6 \\
\hline limonene & 0.27 & 0.03 & 9.03 & 0.24 & 6.67 & 66.7 \\
\hline nzaldehyc & 1.00 & 2.41 & 0.41 & -1.42 & 2.04 & 6.52 \\
\hline 4-dichlorobenzene & 0.02 & 0.01 & 3.41 & 0.02 & 0.18 & 42.2 \\
\hline tanal & 0.66 & 0.15 & 4.51 & 0.51 & NA & NA \\
\hline decamethylcyclopenta & & 0.11 & 87.2 & 9.58 & NA & NA \\
\hline -siloxane ${ }^{a}$ & 9.69 & & & & & \\
\hline Inana & 1.85 & 0.31 & 5.94 & 1.54 & 3.02 & 8.14 \\
\hline & 0.54 & 0.34 & 1.57 & 0.19 & NA & 9.62 \\
\hline thalene & 0.06 & 0.01 & 4.74 & 0.05 & NA & 9.95 \\
\hline & 2.57 & 0.35 & 7.40 & 2.22 & NA & NA \\
\hline ineol & 0.01 & 0.01 & 2.09 & 0.01 & NA & NA \\
\hline & 0.20 & 0.01 & 40.4 & 0.20 & 2.35 & 10.4 \\
\hline iylphthalate & 0.16 & 0.01 & 32.3 & 0.16 & 0.05 & 6.00 \\
\hline aldehyde & 4.59 & 1.239 & 3.70 & 3.35 & 15.7 & 44.2 \\
\hline eny & 3.75 & 2.728 & 1.37 & 1.02 & 7.76 & 17.2 \\
\hline etone & 5.35 & 2.536 & 2.11 & 2.82 & NA & NA \\
\hline
\end{tabular}




\section{Appendix A - Methods}

The parameters measured in each space included ventilation rate, airborne concentrations of carbon dioxide, carbon monoxide, airborne fine particles, total particle number, black carbon particulate matter, and 32 selected volatile organic compounds including formaldehyde. Temperature and relative humidity were measured as well. Most of these parameters were measured at two locations within each floor. Measurements were made over one entire workday starting at about 9:00 AM and ending at 5:00 PM.

The two study spaces are substantially different. Floor 15 East, approximately $8250 \mathrm{ft}^{2}$ $\left(107,250 \mathrm{ft}^{3}\right)$, is naturally ventilated via a set of opening windows on the North and South faces of the building. A set of trickle ventilators at floor level on the windward side of the building are mechanically opened under automatic control. A corresponding set of relief windows set high on the leeward side open to exhaust the air at the other side of the building. The system is symmetrical, allowing either façade of the building to be the outdoor air supply depending upon the prevailing winds. A larger set of operable windows is available on either side of the building for use at the discretion of the occupants. A series of mechanically ventilated and air-conditioned office cabins are placed in the central floor area of the naturally ventilated floor wings. The design intent of these cabins was for their ventilation air to be more-or-less isolated from the surrounding space by a requirement that the occupants keep their doors closed. In operation it appears that the doors are seldom closed during work hours.

The mechanically ventilated floor, Floor 5 East, approximately $8250 \mathrm{ft}^{2}\left(66,000 \mathrm{ft}^{3}\right)$, operates using a traditional air-handling unit (AHU) built into a mechanical room in each wing. Outside air is drawn into the AHU at the North façade of the building, and the exhaust air is relieved at that elevation. Air is distributed through the space from standard ceiling diffusers while the return air transits through ceiling return grilles and slotted light fixtures into a ceiling return plenum.

The building materials are of a high grade with obvious attention to selection for low emissions. Much of the space, including walls and ceilings is finished with the structural concrete, steel, aluminum, and glass. Floors are carpeted. Wood trim appears to be a light hardwood with an oiled finish. Furniture made use of metal framework with hard plastics and fully encapsulated wood cabinetry and work surfaces.

Ventilation rates were measured using the sulfur hexafluoride $\left(\mathrm{SF}_{6}\right)$ tracer gas decay method (ASHRAE 1999). The injection was conducted shortly before noon, as many of the office workers departed for lunch break. In the case of the naturally ventilated space, tracer gas was injected from a lecture cylinder in small bursts by the technician as he walked slowly around the perimeter of the space. In preparation for the injection, to ensure the requirement of thorough mixing of the tracer throughout the space, desk fans were placed in the doorway of each of the central cabin offices and turned on their highest setting to mix the tracer gas. The injection process lasted for about 10 minutes. A portable infrared $\mathrm{SF}_{6}$ analyzer (Miran SapphIRE) was used to verify that the tracer gas was well mixed throughout the space to a homogeneous initial concentration. Once homogeneity was verified, the fans were turned off and removed from the space. At this 
point, three Miran SapphIRE instruments that had been distributed within the space were used to monitor the decaying $\mathrm{SF}_{6}$ concentration. The decay data were used to calculate the whole-space air exchange rate. In the case of the mechanically ventilated floor, a homogeneous $\mathrm{SF}_{6}$ concentration was a easily achieved by injecting the $\mathrm{SF}_{6}$ into a return air duct in the space and allowing the air distribution to mix the tracer gas.

Indoor and outdoor air quality parameters were measured using a set of instruments installed on equipment carts. The indoor carts were located at two distinctly different locations at opposite ends of the spaces. Each cart held a Fuji ZPF9 infrared $\mathrm{CO}_{2}$ monitor, a Met-One ${ }^{\mathrm{TM}}$ 6-size-bin particle counter, a VOC sampling pump, an aldehyde sampling pump, a Hobo ${ }^{\mathrm{TM}}$ temperature (T) logger, and a Hobo ${ }^{\mathrm{TM}}$ relative humidity (RH) logger. One indoor cart and the outdoor cart was equipped with an Aethalometer ${ }^{\mathrm{TM}}$ to measure black carbon particulate matter, a condensation particle counter to measure total particle count concentrations, and TSI Qtrak ${ }^{\mathrm{TM}}$ that measures $\mathrm{CO}, \mathrm{CO}_{2}, \mathrm{~T}$ and $\mathrm{RH}$.

The VOC samples were collected on multisorbent thermal desorption tubes while aldehyde samples were collected on DNPH cartridges. Exposed sampling media were stored on ice packs after sampling and returned to LBNL for analysis. The VOC samples were analyzed by thermal desorption - gas chromatography mass spectrometry with a system calibrated for the specific compounds in this report. Likewise, the DNPH cartridges were analyzed for formaldehyde and acetaldehyde using High Performance Liquid Chromatography.

On both floors, the ventilation settings were set to their minimum outside air conditions, e.g., the conditions most likely to be encountered in the spaces under normal operating conditions. In the case of Floor 15, this was accomplished by having the building manager put the control system into "Mode 3". Mode 3 operates with the trickle ventilators on the windward side of the building open and the upper vent window on the leeward side open. In the case of Floor 5, the air-handling unit outside air vent damper was locked in minimum outside air mode for the sampling day. Since the system was in heating mode during the day of May 14, the system would have automatically been operating in this mode anyways. 